\title{
Recent patents in phage display
}

\begin{tabular}{ll} 
Patent \# & Subject \\
\hline WO 200039580 & $\begin{array}{l}\text { An assay device comprising an array of specific binding } \\
\text { molecules that will bind partner molecules in a chemical } \\
\text { or phage display library to produce characteristic patterns; } \\
\text { useful for diagnosing cancer or immune system disease. }\end{array}$ \\
WO 200038515 & $\begin{array}{l}\text { Treating cancer or melanoma in a mammal, comprising } \\
\text { administering a peptide mimic to generate an immune } \\
\text { response against the target molecule or its fragment } \\
\text { associated with disease. Peptide mimics of the high- } \\
\text { molecular-weight melanoma-associated antigen } \\
\text { (HMW-MAA) identified using phage display peptide libraries } \\
\text { are able to stimulate clones that recognize the HMW-MAA, } \\
\text { but have not been deleted during the establishment of } \\
\text { self-identity because of their reduced affinity. }\end{array}$ \\
WO 200029004 phage display library comprising a number of recombinant \\
$\begin{array}{l}\text { phage, each of which has an expression vector encoding a } \\
\text { single domain of the variable region of the heavy chain of an } \\
\text { antibody molecule, and an isolated phage clone that binds } \\
\text { selectively with a specific antigen of interest; useful for the } \\
\text { diagnosis and treatment of disease. }\end{array}$ \\
$\begin{array}{l}\text { Novel nucleic acids encoding cb1-SL proteins. The cb1-SL } \\
\text { proteins or fragments can be used to screen phage display } \\
\text { libraries to identify and select peptide-binding partners of } \\
\text { the cb1-SL polypeptides, which can be used for screening } \\
\text { assays, for purification protocols, and for interfering directly } \\
\text { with the functioning of cb1-SL. Useful for treating cancers } \\
\text { expressing a mutant cb1-SL polypeptide. }\end{array}$ \\
WO 200027865
\end{tabular}

WO 200026230 A method for selecting a protein variant having reduced immunogenicity as compared to a parent protein, comprising screening a random peptide display package library with antibodies raised against the protein of interest.

WO 200023580 An improved method of affinity separation, including a method of phage display in which a protein expressed on the phage surface has one or more of its asparagine residues modified in a separate step from the modification of the protein's binding characteristics. Useful for testing the presence of and for yielding pure samples of a target molecule.

WO $200023463 \quad$ Novel fluorette peptides that bind with high specificity to fluorophore dyes; useful for detecting biological materials, molecules, target analytes, intracellular events, and intraand intermolecular interactions, as well as discovering effective inhibitors.

WO 200020573 DNA shuffling methods to improve mycotoxin detoxification genes for use in agricultural and industrial processes to degrade mycotoxins; includes selecting one or more mycotoxin detoxification nucleic acids (MDNAs) for encoded mycotoxin detoxification activity or for enhanced or reduced encoded polypeptide expression or stability.

WO 200023465 Generation of a peptide with a selected biological activity, comprising displaying the peptides on the outer surface of a genetic display package to create a peptide display library, and using affinity selection to enrich the population display packages for those containing peptides that have desired specificity to the target cell; useful for identifying endothelial inhibitors and peptides with antiangiogenic activity.

Assignee
Univ. of Sydney

(Australia)

New York Medical

Coll. (New York)

Peptor Ltd.

(Rehovot, Israel)

Plaksin D

$5 / 25 / 20000$

A1

Brigham \& Womens Hospital

(Boston, MA)

Novo Nordisk

(Bagsvaerd,

Denmark)

Affibody

Technology

Sweden

Stanford Univ.

(Stanford, CA)

Nolan GP;

Rozinov MN

$4 / 27 / 2000$

A2

Maxygen

(Redwood City, CA)

Subramanian V

$4 / 13 / 2000$

A2

Mitotix

(Cambridge, MA)
Gyuris J, Morris AJ

$4 / 27 / 2000$

\section{A1}

Ernst S, Olsen AA, $\quad 5 / 11 / 2000$

Gardner R, Hober S， 4/27/2000

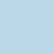

A1

